\title{
植物, 微生物でのフェニルプロパノイドの生合成
}

\author{
南川隆雄 \\ 東京都立大学理学部生物学教室
}

植物, 微生物での $\mathrm{C}_{6}-\mathrm{C}_{3}$ を骨格とするフェニルプロパ ノイドの生合成は，いわゆるシキミ酸経路（図 1）によ っておこなわれる. 微生物では, この経路は生体にとっ て必須な芳香族アミノ酸であるフェニルアラニン (Phe) とチロシン (Tyr) を合成する重要な役割を果たしてい る.さらに, この経路を中心として, 一方ではもら1つ の芳香族アミノ酸であるトリプトファン (Try) の生合 成，またビタミン $\mathrm{K}$ やーアミノ安息香酸などの合成系 が接続している，高等植物では，生成されたPhe や Tyr のある部分はついで脱アミ,されて桂皮酸類, クロ ロゲン酸などのフェノール物質, クマリン類, さらには フラボノイドやリグニンの形成へと導かれる。高等植物 でのシキミ酸経路の研究は, これら Phe, Tyr を経て生 成される植物成分の生合成の研究とあわせて, つぎつぎ と新しい成果が得られている。ここでは，この 1,2 年 の間に報告された高等植物でのフェニルプロパノイド生 合成についての研究結果を前半にまとめ, 後半では, 微 生物での芳香族アミノ酸生合成の代謝調節をとりあつか った研究グループの任事を概観したいと思う。な拉, 高 等植物での Phe, Tyr から生成されるフェニルプロパノ イドの代謝は, 吉田の総説(1)に詳しく最近の研究が紹介 されている.

\section{高等植物でのシキミ酸経路の最近の研究}

$\mathbf{C}_{7}$-化合物の形成：糖の代謝系に連なるシキミ酸経路 の入口に位置する反応は, エリスロース-4-りん酸(E4P) とフォスフォエノールピルビン酸 (PEP) の縮合である ここで生成される最初の $\mathrm{C}_{7}$-化合物, 3-デオキシーDーア ラビノーヘプッゥロソン酸-7-りん酸 (DAHP) は, $\mathrm{Co}^{2+}$ と NAD 存在下で環を形成してデヒドロキナ酸となる. 微生物では, DAHP シンテターゼは Srinivasan ら(2) により Escherichia coli 抽出液から精製されて和り, 後 述するように，この酵素反応は微生物での芳香族アミノ 酸生合成の調節機作に関与している。

高等植物で, 糖代謝とシキミ酸経路の初段階を結びっ けたのは, Yoshida ら (3) の ${ }^{14} \mathrm{C}-$ 化合物を用いた研究で
ある.かれらは種々の ${ }^{14} \mathrm{C}-$ 化合物をマッの幼苗に与えて， これらのシキミ酸への代謝をしらべているが，ピルビン 酸が最も有効な前駆物質であり，またグルコース- ${ }^{14} \mathrm{C} を$ エリスロースとともに与えると, 生成したシキミ酸の比 放射能が稀釈されるなどの結果を得ている.これらのin vivo の実験は, 植物に持ける DAHP シンテターゼの存 在と役割を充分に推察させた。その後, Nandy ら ヤエナリ幼芽の粗抽出液を用いて，6炭糖り几酸がデヒ ドロシキミ酸生成の前駆物質になることを確かめ, とく に E4P と PEP を同時に与えたときに最も有効である ことを報告している。この実験では，生成したデヒドロ シキミ酸を bioassay によって定量しているが，用いた 粗酵素液に含まれる補酵素の存在下で，直接の生成物 DAHP はさらに先の段階に進んだものと考光られる、筆 者ら ${ }^{(5)}$ は, サッマイモ塊根のアセトン粉末からの抽出液 をセファデックス (G-25) のカラムでゲル濾過して低分 子物質を除いて得た粗酵素液が，DAHP シンテターゼ 活性をもっていることを見いだしている，この反応は，

$\mathrm{Mg}^{2+}$ (1 mM) の添加により反応速度が $60 \sim 120 \%$ 程度 増す点で, E. coli の DAHP シンテターゼと多少性質が 晎なるが，高等植物で明瞭にこの酵素反応をとらえたこ とに意義があると思う. サッマイモ塊根を切片にして， これを $30^{\circ} \mathrm{C}$ で 1〜4 日間放置すると, 後述するように, その傷害部分にクロロゲン酸 (3-O-カフェオイルーDーキ ナ酸）を主とするポリフェノール物質の合成がみられ， それに先だち，この合成に関与するシキミ酸経路の数種 の酵素が活性增加を示す.ところが，しらべた酵素のら ちで DAHP シンテターゼのみは，切断傷害を与えて後 4 日の間ほとえど活性の変化はみられなかった（図 2). この場合, その活性は著量のポリフェノール物質合成に 要する $\mathrm{C}_{7}$-化合物の形成に充分みあらが, この酵素のみ が他の酵素と異なり変動を示さないことが，傷害サッマ イモでのフェニルプロパノイド合成系の活性化にどらい う意味をもっているかは，今のところ不明である。なお， 他の数種の植物材料についても DAHP シンテターゼ活 性の分布をしらべたが (表 1)，いずれの場合も1〜 $5 \mathrm{~mm}$ 


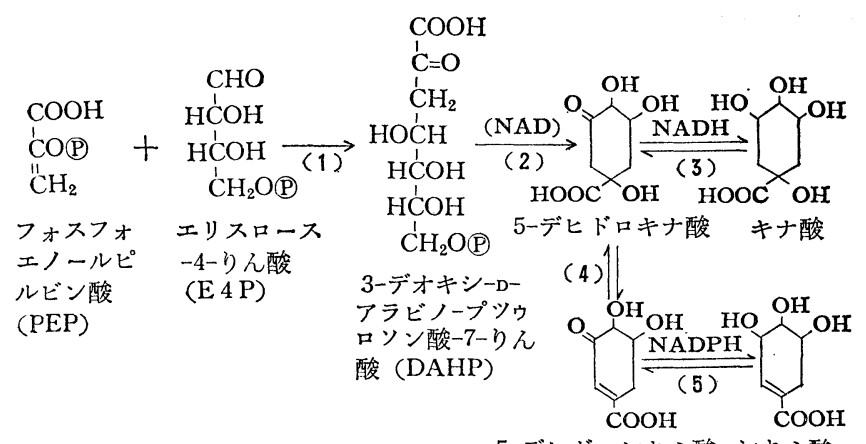

5-デヒドロシキミ酸 シキミ酸

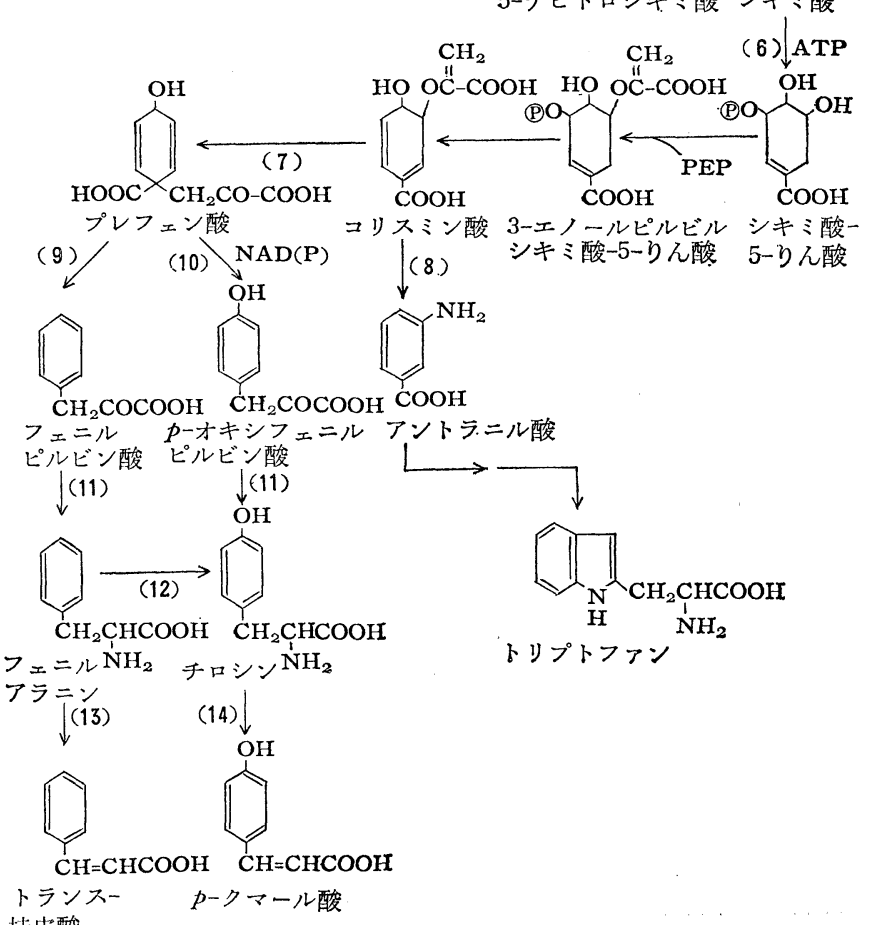

図1フェニルプロパノイド生成のシキミ酸経路

酵素名：(1) DAHP シンテターゼ，（2）デヒドロキナ酸シンテターゼ，（3）キ ナ酸デヒドロゲナーゼ，(4) 5-デヒドロキナ酸デヒドラターゼ，（5）シキミ酸デ ヒドロゲナーゼ，（6）シキミ酸キナーゼ，（7）コリスミン酸ムターゼ，（8）アン トラニル酸シソテターゼ，(9) プレフェン酸デヒドラターゼ，(10)プレフェン酸 デヒドロゲナーゼ, (11) 芳香族アミノ酸トランスアミナーゼ, (12) フェニルアラ ニンヒドロオキシラーゼ，（13）フェニルアラニンデアミナーゼ, (14) チロシンデ アミナーゼ

表 1 高等植物の DAHP シンテターゼ活性

\begin{tabular}{|c|c|c|}
\hline \multirow[b]{2}{*}{ 材 } & \multicolumn{2}{|c|}{ 醖素活性 (m $\mu \mathrm{mole} /$ 分) } \\
\hline & $\begin{array}{l}\text { アセトン粉末 } \\
\text { g当り }\end{array}$ & $\begin{array}{l}\text { 粗蛋白質 } \\
\mathrm{mg} \text { 当り }\end{array}$ \\
\hline サツマイモ, 塊根 & $14 \sim 19$ & $0.95 \sim 1.23$ \\
\hline シロッメクサ, 成葉 & $32 \sim 44$ & $0.44 \sim 0.56$ \\
\hline ヤエナリ, 幼茥 & 126 & 2.37 \\
\hline ヤエナリ, 幼葉 & 71 & 1.01 \\
\hline ヨモギ, 若い葉 & 9 & - \\
\hline イチョウ, 若い葉 & 0 & - \\
\hline ゼソマイ, 若い葉 & 0 & - \\
\hline
\end{tabular}

Vol. 5, No. 5
の $\mathrm{Mg}^{2+}$ が活性を高めることがわか った.

シキミ酸の形成： シキミ酸経路 での最初の安定な脂環族化合物は， DAHP より生成する 5-デヒドロキ ナ酸である、5-デヒドロキナ酸と 5-デヒドロシキミ酸は生体内では平 衡状態にあり, Aerobacter aerogenes ではそのモル比は 1:15 で, 反 応はフェニルプロパノイド生成の方 向に傾いている。この可逆反応を触 媒する酵素, 5-デヒドロキナ酸デヒ ドラターゼは, 植物では Mitsuhashi $ら^{(6)}$ がエンドウ, ホウレンソウ葉 に最初に見いだし，後に Balinsky $ら^{(7)}$ がカリフラワーから精製し性質 をしらべている.5-デヒドロシキミ 酸は，つぎに NADP を補酵素とす るシキミ酸デヒドロゲナーゼ作用に よってシキミ酸となる。この酵素は Balinsky ら ${ }^{(8)}$ により高等植物での 分布と性質がしらべられた。

サッマイモ塊根に和いてもこれら 2 つの酵素活性は存在し, 正常組織 でのPheなどの芳香族アミノ酸合 成に関与していると思われる。この 組織を切断して傷害を与えると, 放 置後 1 日のうちに両酵素の活性は 3 〜4 倍に増加している( ${ }^{(9)}$ (図 2).こ のことは, サッマイモでのフェニル プロパノイド合成の終段階に関与す るフェニルアラニンデアミナーゼの 活性堌加 ${ }^{(10)}$ に加えて, 合成経路の かなりの前段階に関わる酵素の活性 増加が傷害により発現してくること を示しており，この場合は微生物にみられるような代謝 経路のなかの特殊な律速酵素をもつというよりは, 経路 の全体が活性化してくることを推察させる。

フェニルアラニンデアミナーゼは組織を切断した後 4 時間ですでに活性の発現が観察され，また最近の小島ら の研究では, シキミ酸デヒドロゲナーゼはわずか 2 時間 で活性の増加がみとめられている．外的環境の変化に対 する反応が遅いといわれる高等植物に执いて，このよう な短時間のうちに酵素活性の変動がみられることは注目 


\begin{tabular}{|c|c|c|c|c|c|c|}
\hline \multirow[b]{2}{*}{ 材 料 } & \multicolumn{2}{|r|}{ 酵 } & 性 & \multicolumn{2}{|c|}{ (mole/分/mg 㔻白質) } & \multirow[b]{2}{*}{$\begin{array}{l}\text { チロシソデア } \\
\text { ミナーゼ }\end{array}$} \\
\hline & $\begin{array}{l}\text { キナ酸デヒド } \\
\text { ロゲナーゼ }\end{array}$ & $\begin{array}{l}\text { 5-デヒドロキ } \\
\text { ナ酸デヒドラ } \\
\text { ターゼ }\end{array}$ & $\begin{array}{l}\text { シキミ酸デヒ } \\
\text { ドロゲナーゼ }\end{array}$ & $\begin{array}{l}\text { プレフェソ酸 } \\
\text { デヒドロゲナ } \\
\text { 一ゼ }\end{array}$ & $\begin{array}{l}\text { フェニルアラ } \\
\text { ニンデアミナ } \\
\text { ーゼ }\end{array}$ & \\
\hline ヤエナリ，根 & 4.5 & 13.5 & 167 & 52.5 & 6.5 & 5.5 \\
\hline ソラマメ，根 & 0 & $19 \cdot 2$ & 69.0 & 51.8 & 0 & 2.4 \\
\hline ワサビ，葉柄 & 0 & 10.9 & 60 & 0 & 0.9 & 1.6 \\
\hline バ ラ, 茎 & 0 & 36 & 250 & 0 & 1. 7 & 11.1 \\
\hline ジャガイモ, 塊茥 & 0 & 5.1 & 57 & 0 & 0 & 4.6 \\
\hline
\end{tabular}

されてよいだろう。この場合, デアミナーゼ活性の増加 が蛋白質合成抑制剂などで阻害されることから類推して， シキミ酸デヒドロゲナーゼなども，傷害により增加する 部分は酵素蛋白質の de novo 合成によっていると考学る のが妥当であろう. 切断傷害という現象が何を仲介とし てこのような酵素活性の增加に結びついているかは今後 の課題として残されて物り，この問題には，動物や微生 物とは異なった，高等植物に扣ける代謝の変動をるたら す因子を解明しょうとする意味が含まれている。

キナ酸の代謝：以前には, キナ酸はシキミ酸との構 造上の類似性から，これがシキミ酸経路の主路にくみこ まれているのではないかと考它られたことがあった。そ の後, Mitsuhashi ら ${ }^{(11)}$ は A. aerogenes の変異株からキ ナ酸デヒドロゲナーゼをはじめて見いだし，その性質を しらべた。この酵素反応によって，A. aerogenes では キナ酸はデヒドロキナ酸となり、シキミ酸経路のなかに 入る斿けである(図1参照).したがって，キナ酸デヒド ロゲナーゼ反応はシキミ酸経路の 1 つの横道と考光てよ
く, 事実, A. aerogenes 以外の微生物ではこの酵素が 欠損していることが知られている。

高等植物には，キナ酸やクロロゲン酸のようなキナ酸 のデプシドはきわめて多種にわたって分布しておらり，な かにはこれらの含量が著しく高い植物も少なくない。サ ッマイモ塊根では新鮮重 $\mathrm{g}$ 当り約 $5 \mu \mathrm{mole}$ のキナ酸を 含み, この含量は傷害組織では徐々に減少して切断後 4 日目でほ涪半分になる(12)。この減少部分は扔そらくク ロロゲン酸合成に消費されていると思われるが，合成さ れるクロロダン酸との量的割合からみると，その間キナ 酸はさらに新たに合成, 供給されていると考光られ，1 つの活発な代謝物質であるとみることができる．

植物でのキナ酸の代謝を手がけたのは，Weinstein ら ${ }^{(13)}$ である. バラにキナ酸- ${ }^{14} \mathrm{C}$ を光，その代謝をし らべたところ, シキミ酸へのとりこみが最も高く, Phe, Tyr ヘのラベリングもみられた. かれらは10 種ほどの 植物材料について同様の結果を得，キナ酸がかなりの効 率でフェニルプロパノイド合成の前駆物質になることが 高等植物一般について言いうること を確かめた。 そこで，キナ酸とデヒ ドロキナ酸との相互転換が高等植物 でも予想されたのは当然であった。

最近, Gamborg ${ }^{(14)}$ は数種の植物 組織の䯚濁培養 (liquid suspension culture) によって得た細胞を用い て, シキミ酸経路の主な䣼素の活性 をしらべているが，このなか沉キナ 酸デヒドロゲナーゼ活性をみとめた と報告している（表 2)．この酵素 はヤエナリの培養組織のみに検出さ れているが, 高等植物のキナ酸デヒ ドロゲナーゼをみとめた最初の報告 といえる. 幼根の培養で得た細胞か ら部分的に精製したキナ酸デヒドロ ゲナーゼの性質は, Aerobacter の 
酵素とよく似ている.NAD を補酵素とし，NADP はこ れにかわりえない，NAD とキナ酸に対する $K_{m}$ 值は拉 の拈の $0.031 \mathrm{~mm}$ と $0.32 \mathrm{~mm}$ である(15). 今のところ, この酵素の活性はヤエナリにしか見つかっていないが， 他の植物組織での検出の難しさは, 抢そらく抽出操作中 の不活性化によるものだろら．

以上のような実験事実から推察すると, キナ酸はシキ ミ酸経路のなかに直接含まれてはいないが，1つにはク ロロゲン酸なぞのキナ酸デプシドへの移行, むう1つに はキナ酸デヒドロゲナーゼ反応によるシキミ酸経路への $\mathrm{C}_{7}$ 一骨格の供給という面を通じて，フェニルプロパノイ ド生合成に活発な役割を演じているといえる，後者の場 合は, むしろシキミ酸経路での $\mathrm{C}_{7}$-化合物の流れの增減 に関わる緩衝的な役割をもっていると言いかえることが できる。

フェニルアラニンとチロシンの形成： 微生物ではシ キミ酸はATPを消費してシキミ酸-5-りん酸となり,こ れはこの経路 2 つ目のPEP と結合して3-エノールピル ビルシキミ酸-5-りん酸となる。この化合物は脱りん酸 してコリスミン酸を形成する.コリスミン酸は，つぎの プレフェン酸を経る Phe と Tyr の合成系と, アントラ ニル酸を経る Try 合成系との分岐点に位置する重要な 中間物質である、高等植物でのこのあたりの酵素系は, まだまったく未解決のまま残されているといってよく， 推定の域を脱していない.

コリスミン酸からムターゼ作用により生成されるプレ フェン酸は, E. coli の Phe 要求株から単離同定された. E. coli 野生株ではこのプレフェン酸はフェニルピルビ ン酸に移行し, シキミ酸経路での初の芳香環を形成する。 これを触媒する酵素, プレフェン酸デヒドラターゼの詳 しい研究はまだなされていない.フェニルピルビン酸は つぎにトランスアミナーゼにより Phe になる。一方で は, プレフェン酸は E. coli のデヒドロゲナーゼにより， NAD を補酵素として $p$-オキシフェニルピルビン酸とな り，さらにトランスアミナーゼにより Tyr を形成す $ろ^{(16)}$ (図 1 参照).

高等植物でのプレフェン酸から Phe と Tyr そ至る経 路ははなはだ不明膫であったが, Gamborg ら ${ }^{(17)}$ の研究 がその端緒を与えているだろう，かれらは，ヤエナリの 無細胞液が芳香族アミノ酸トランスアミナーゼ, プレフ ェン酸デヒドラターゼ, プレフェン酸デヒドロゲナーゼ の活性をもつことを見いだしている。これにつづく報 告(18) では, マメ科幼植物の子葉のプレフェン酸デヒド ロゲナーゼの性質と, 生長に伴うデヒドロゲナーゼとト
ランスアミナーゼの消長をしらべている，また，前述の 䀣濁培養組織にもこれらの酵素活性がみとめられている (表 2). 高等植物のプレフェン酸デヒドロゲナ゙ーゼは $\mathrm{NADP}$ を補酵素とし，NAD を必要とする微生物の酵 素と異なる点が特筆される.

プレフェン酸から Phe と Tyr に至る道すじも微生物 と共通のものであることは，植物一般に言いらることだ ろらが，サッマイモではまだこのあたりの研究はなされ ていない，傷害サッマイモのよらなフェニルプロパノイ ド生合成系が短時間のうちに活発化してくる植物組織を 用いて，これらの酵素の性質と傷害に伴う活性変動を追 跡することは，そのことに有力な確証を与えるだろう．

な持, 微生物之高等植物では, 動物組織之異なり, Phe プールの Tyr への直接の移行は，あってもきわめ， てわずかであると考光られて拈り，Tyr の大部分は $p-$ オキシプレフェン酸を経て形成されると思われる。しか し, Nair ら ${ }^{(19)}$ はホウレンソウ葉の抽出液が Phe を水 酸化して Tyr を生成しらることを報告して叔り，同じ 材料から精製したフェニルアラニンヒドロオキシラーゼ を得ている。この酵素反応はテトラヒドロ葉酸と還元型 ピリジンヌクレオチドを必要とし, 酵素学的諸性質は動 物の肝臓から得た酵素と非常に類似している. そして, ホウレンソウから抽出された補助因子はプテリジン誘導 体と推定され，これはテトラヒドロ葉酸にとってかわる ことができる。これらの知見は，高等植物での Tyr の 形成が，必ずしも $p$-オキシフェニルピルビン酸を経て のみ起こるとは言いきれないことを示している。

\section{微生物での芳香族アミノ酸生成の調節機作}

\section{E. coli での DAHP シンテターゼの芳香族アミノ酸} による阻害と生成抑制： E. coli 83-24 変異株はシキミ 酸蓄積株であるが，この培地に Phe とTyr を入れてや ると, シキミ酸の蓄積が著しく減少することが知られて いた．たとえば Phe と Tyr それぞれ $0.1 \mu \mathrm{mole} / \mathrm{ml}$ を添加するとシキミ酸合成を対照区の $1 \%$ に減少させる。 このさい,アミノ酸とともに E4P や PEP のようなシ キミ酸合成に非常に近い基質を与兄ても, アミノ酸添加 による効果はとり除くことはできなかった，以上のよ らな事実から，E. coli での芳香族アミノ酸合成の抑制 機作がその生成経路の初段階に位置する反応, つまり DAHP シンテターゼ作用のなかに含まれていることが, 他のアミノ酸などの代謝抑制の機作とも考光あわせて， 推定されたのであった. Smith ら(20) はここに着目して, 83-24 株の DAHP シンテターゼが硫安分画によって2 
(a)E.coliでのレプレッションとフィードバック阻害

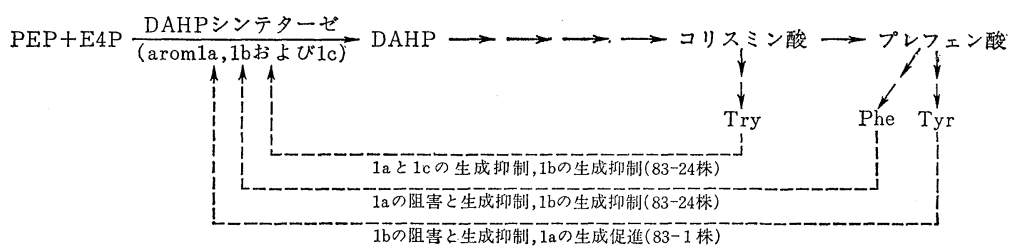

(b)B.subtilis でのフィードバック阻害

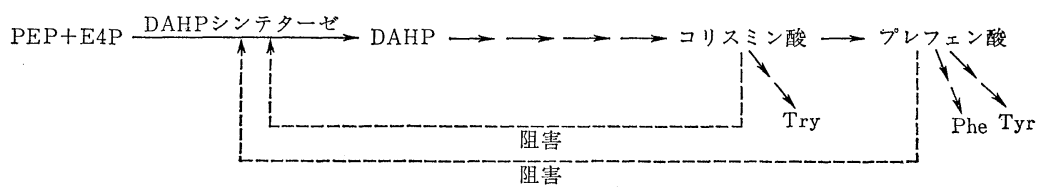

(c)N.crassaでの阻害と促進

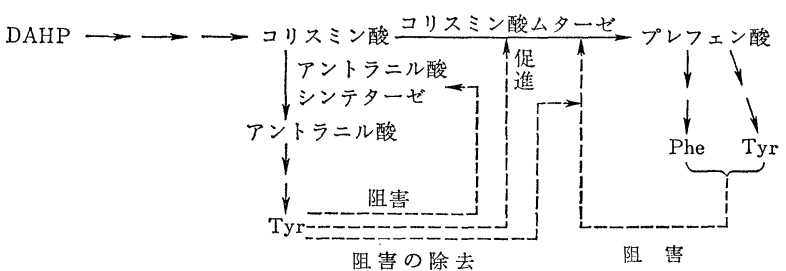

図 3 微生物での芳香族アミノ酸生合成の代謝調節の様式

つの成分に分けられることを見いだした．硫安の 35〜 $50 \%$ 飽和の分画で得られるシンテターゼは Tyr によっ て非拮抗的阻害をらけ，もう一方の $60 \sim 70 \%$ 飽和で得 られるシンテターゼはPhe によって阻害される。 さら に，このような酵素活性の阻害とは別に, Tyr 阻害のシ ンテターゼは低濃度 (3 mM) の Tyr によりその生成が 抑制され，他のPhe 阻害のシンテターゼは Tyr により 生成に影響をうけないことがわかった，反対に，Phe の 高濃度 $(10 \mathrm{~mm})$ は双方の酵素の生成をとるに抑制する。

その後, Brown ら ${ }^{(21)}$ は, E. coli 野生株での DAHP シンテターゼが芳香族アミノ酸による酵素阻害とレプレ ッションの様式を異にする 3 種の成分に分けられること を見いだした。この酔素が芳香族化合物生成の初段階反 応位置することから，これら 3 種の成分はそれぞれ arom $1 \mathrm{a}$ (Phe 阻害), arom $1 \mathrm{~b}$ (Tyr 阻害), 拉よび arom 1c (Phe, Tyr で阻害されない) と名づけられた。 これらの DAHP シンテターゼは, アミノ酸によるフィ 一ドバック阻害のほかに，酵素生成に対する抑制をるう ける. Arom 1a は Phe で, $1 \mathrm{~b}$ は Tyr で強く生成が 抑制され，1c は Tryにより抑制される（図3 (a)). すなわち， 3 種の酵素は 3 種のアミノ酸により，叔の拉 の独立にレプレッションをうけ，また阻害されているよ らである。しかし, この明解な調節様式のほかに, つぎ のような “cross repression” や “inductive effect” の
現象もみられる. Arom 1 a は Phe のほかに Try でも レプレッションをうける。また 83-24 株では， $1 \mathrm{~b}$ は Phe や Try によってもレプレッションをらける.さらら に $1 \mathrm{a}$ には Tyr による生成の誘導効果がみられ, Tyr の添加によって 1a の Phe または Try による生成抑 制はある程度効果を低下させる。この現象は最小アミ， 酸培地で培養した多数アミノ酸要求株 83-1 の場合に明 らかにみられ，培地中に過剩の Tyr を添加すると，と くに增殖期に打いて $1 \mathrm{a}$ のレベルがか党って增加するこ とが知られている(21).

Bacillus subtilis での DAHP シンテターゼの代謝 中間物によるフィードバック阻害 : B. subtilis の DAHP シンテターゼは, 粗抽出液に比べて 77 倍に精製されて 拈り, 物理学的, 酵素学的諸性質から, E. coli の酵素 と異なり 1 成分よりなることがわかっている(22)。この DAHP シンテターゼに対するフィードバック阻害は, 先の E. coli に抢けるものとは異なる代謝抑制の例を示 していて興味深い。すなわち, この酵素は, 芳香族アミ 八酸生合成の枝分かれ点に位置する 2 つの中間物質，コ リスミン酸とプレフェン酸により活性阻害をうける（図 3 (b)). 両物質による阻害は完全に非持抗的で, 酥素の コリスミン酸とプレフェン酸に対する $K_{i}$ 值は，抒のお の $0.28 \mathrm{~mm}$ 拉よび $0.04 \mathrm{~mm}$ である. しかも酵素分子 上には阻害物質の複数の結合部位があり，その間に協同 
作用のあることが，プレフェン酸とコリスミン酸双方に ついて観察されている，阻害物質の濃度に対する阻害率 の関係をグラフにしてみると，曲線はシグモイド型を示 す。齐つらの酵素の非拮抗的阻害ならばその曲線は双曲 線型となるが，この場合のようにシグモイド型を示すこ とは，可逆的に形をか兄る酵素分子上の 2 つたはそれ 以上ある結合部位の間隹同作用があって，阻害物質の 濃度を高めてゆくと，その結合能がしだいに增してくる と解秎することができ，アロステリック蛋白質を研究す るら光に貴重な新例を提供している。な拈，これらの阻 害効果は低温下では強められることがわかっている。よ く知られたアロステリック酵素について, このよらな温 度と阻害率との関係をくわしくしらべた研究はまだない が, 相対的に低温下の反応では調節醰素の阻害が大きく なるのは，むしろ一般的な現象であるのかもしれない。 実際の生体内で, もし菌体が低温下に扔かれた場合, 細 胞内の代謝物質ないしは阻害物質の濃度が低下すると, その低濃度でもって，至適温度に拈けると同じょうなア ロステリック阻害剤としての能力を維持するために，低 温下では阻害能力を增すという目的性をとな光ている可 能性も考光られる。

\section{さて，B. subtilis の DAHP シンテターゼのように，} 最終産物ではなく，いわば中間物質によって代謝経路の 初段階が阻害される例は珍しい.ふらつうの意味での代謝 中間物質によるフィードバック阻害が実際の生体内で起 こるためには，細胞はこれを維持する機構をそなえてい るはずで, B. subtilis では比較的高濃度のコリスミン酸, プレフェン酸を蓄積していると考えなくてはならない.

Neurospora crassa でのコリスミン酸ムターゼの芳 香族アミノ酸による阻害と活性化：A. aerogenes や $N$. crassa では, Try はその生合成経路の枝分かれ点の最 初に位置するアントラニル酸シンテターゼのフィードバ ック阻害剂として働くことがわかっている(23,24). とこ ろが一方では, Try は他の芳香族アミノ酸である Tyr とPhe の生合成に関与する酵素, コリスミン酸ムター ゼの賦活剤になりらることが $N$. crass $a$ で見いだされ た (25)（図3（c））。コリスミン酸ムターゼ活性の基質飽 和曲線は，Try のないときにはシグモイド型であり， 典型的なアロステリック酵素であることを示す．このと きTry の存在は, 最大反応速度には影響なく, $K_{m}$ 值 を小さくする型の賦活剤として働く，さて，他方では N.crassa のコリスミン酸ムターゼは $0.3 \mathrm{~mm} の$ Phe で 65\%, 同濃度の Tyr で 87\% の阻害をうける。この とき Phe や Tyr とともに Try を添加すると, 前 2 者
のアミノ酸による阻害の完全な回復がみられる.

このように N. crassa の芳香族アミノ酸生合成では,

1) Try によるアントラニル酸 シンテターゼの阻害と コリスミン酸ムターゼの活性促進，2）コリスミン酸ム ターゼの Phe と Tyr による阻害とそれの Tryによる 回復効果，といら複雑な調節様式をみせている。したが って, Try の一定濃度は, それ自身の合成経路の阻害と ともに，他のアミノ酸生成をより促進させるという二面 的な役割をもっている．芳香族化合物生成の，このあた りでの代謝の調節機作は，まだ研究のゆきとどいていな いレプレッションの問題をも含めて, 今後しだいに明ら かになってくるであろう.

\section{ま と め}

かつて，シキミ酸経路での 3-エノールピルビルシキ 酸-5-りん酸の次位置すると考光られ, “compound X” と名づけられた化合物が， Cotton ら ${ }^{(26)}$ により, A. aerogenes からコリスミン酸として単離され, 経路 の主要位置にくみこまれたことによって, 微生物に和け る芳香族アミノ酸生成経路の図式はほとんど完成された とい党る. 最近の研究の方向は, むしろ代謝の生体内制 御に向けられてきている観がある。ここに紹介した 2 ， 3 のグループの, その端緒になるべき研究の成果をみる だけでも, 微生物での芳香族アミノ酸生成の調節様式が なかなかの多様性をもっていることがわかる. 今後の研 究は, 経路のなかの個々の酵素の性質の解明とともに， より広範な調節様式の集積と集約の方向にすすめられる であろう。

高等植物でのシキミ酸経路は, シキミ酸キナーゼのよ らにまだ存在が確認されていない酵素もあるが, 近年来 の研究で経路の全貌がかなり明らかになりつつある。高 等植物のシキミ酸経路が，そこに含まれる個々の酵素に 多少の性質のちがいはあるにしても, 今までの研究の範 囲では，微生物でのそれに例外なく一致していることは 注目してよいであろう，先に記したように，高等植物で はフェニルプロパノイドは Phe, Tyr にとどまることな く,さらに脱アミノ反応を経て植物に特有の 2 次物質に 移行することがふつらであり，これらの植物成分生成の 生理的意義解明を背景としたフェニルプロパノイド代謝: の研究が重視されつつある。 その意味では, Zucker の グループが実験材料としているジャガイモ塊茎の切断組 織や，筆者らが一貫して用いてきたサッマイモの病傷害 組織は, 研究のための好適な素材であるといえる.たと 究ばサッマイモ塊根では, 病傷害をうけることによって 
それに応じた代謝変動が起こり，前述のよらに，その一 環として組織中には短時間のらちにクロロゲン酸などの 合成がみられ，これに先だってシキミ酸経路の酵素群の 活性が高まってくる。この事実は, それらの酵素がク口 ロゲン酸に至るフェニルプロパノイド生合成に関与して いることに確証を与えるとともに，一方では，一連の代 謝の変動をしらべるといら面を通じて, 植物が外的条件 飞適応してゆく過程をさぐる糸口を与兄る．このように 植物でのフェニルプロパノイド代謝は生長や分化, 罹病 などの高次の現象のなかに位置づけて，今後の研究がす すめられてゆくべきであろら。

かくして, この種の研究方向は, 単に植物生理学, 病 理学の問題にとどまらず, 各種のフェニルプロパノイド を含む植物性食品の貯蔵, 加工に関する応用領域にも, 重要な知見をもたらすものと思う。

\section{文献}

1) S. Yoshida: Bot. Mag. (Tokyo), 79, 476 (1966).

2) P. R. Srinivasan, D. B. Sprinson: J. Biol. Chem., 234, 716 (1959).

3) S. Yoshida, G. H. N. Towers : Can. J. Biochem. Physiol., 41, 579 (1963).

4) M. Nandy, N. C. Ganguli : Biochim. Biophys. Acta, 48, 608 (1961).

5) T. Minamikawa, I. Uritani : J. Biochem., 61, 367 (1967).

6) S. Mitsuhashi, B. D. Davis: Biochim. Biophys. Acta, 15, 54 (1954).

7) D. Balinsky, D. D. Davies : Biochem.J., 80, 300(1961).

8) D. Balinsky, D. D. Davies : J. Exptl. Bot., 13, 414(1962).

9) T. Minamikawa, M. Kojima, I. Uritani : Plant \& Cell Physiol., 7, 583 (1966).

10) T. Minamikawa, I. Uritani : J. Biochem., 57,678 (1965).

11) S. Mitsuhashi, B. D. Davis : Biochim. Biophys. Acta, 15, 268 (1954).

12) T. Minamikawa : Agr. Biol. Chem., 31, 124 (1967).

13) L. H. Weinstein, C. A. Porter, H. J. Laurencot, Jr.: Contrib. Boyce Thompson Inst., 20, 121 (1959).

14) O. L. Gamborg: Can. J. Biochem., 44, 791 (1966).

15) O. L. Gamborg : Biochim. Biophys. Acta, 128, 483 (1966).

16) I. Schwinch, E. Adams : ibid., 35, 102 (1959).

17) O. L. Gamborg, F. J. Simpson : Can. J. Biochem., 42, 583 (1964).

18) O. L. Gamborg, W. Keeley : Biochim. Biophys. Acta, 115, 65 (1966).

19) P. M. Nair, L. C. Vining: Phytochem., 4, 161, 405(1965).

20) L.C. Smith, J.M. Ravel, S.R. Lax, W. Shive: $J$. Biol. Chem., 237, 3566 (1962).

21) K. D. Brown, C. H. Doy : Biochim. Biophys. Acta, 118, 157 (1966).

22) R. A. Jensen, E.W. Nester : J. Biol. Chem., 241, 3365, 3373 (1966).

23) M. I. Gibson, F. Gibson : Biochem.J., 90, 248(1964).

24) J. A. DeMoss : J. Biol. Chem., 240, 1231 (1965).

25) T. I. Baker : Biochemistry, 5, 2654 (1966).

26) R. G. H. Cotton, F. Gibson: Biochim. Biophys. Acta, 100, 76 (1965).

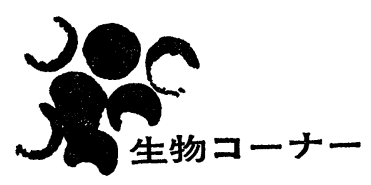

心藏の拍動が，洞房結節に発生する自発性の歩調と り (pace-maker) によって律動的に行なわれ，拍出 された血液が血管との間に生じる血圧も，呼吸運動と からみ合って律動的な変化を示し，末梢循環において は，ある時間血液が流孔ると，そのあと止まり，また， 流机るといら工合に律動的な流机がみられる。このよ らな,ささざまな機能の律動的な動きは，細胞のレベ ルに括いても示されており, 生物学的振動 biological oscillation の現象として知られている.ところで, こ

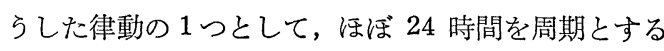
律動, いいかえれば circa diurnal のリズムは, 日周 期律動 circadian rythm または circadian clocks と 名づけられ, 今日, 生命現象の解明に重要性をるつむ のとして重要視されている.

ゴキブリ, カブトムシ, バッタ, ナナフシムシ, シ ヨウジョウバエなどの行動性 locomotor activity, ナ ナフシムシの体色, ゾウリムシの交尾活動や，これら の昆虫の殺虫剤に対する感受性，あるいは，酸素消費 などに日周期律動が存在することがわかってきた。鳥 類において，卵巣で成熟した卵胞は，そこから離れて 体腔に出て (排畉)，卵管に入り，管のなかを下るに つれて卵白が周囲について，次第に卵款が形成されて 体外飞放卵されるが，この排卵，放卵ともに日周期律 動の下にある.したがって，どんなに品種改良を行な ったところで，1日2個の卵を連産させることは不可 能のことがわかる、卵ばかりでなく体細胞の発生もこ の種のリズムの下に行なわれている.たと兊ば, ニワ トリの骨格筋の 線維芽細胞は, 19.9 20.2 時間のリ ズムの下に発生するという，ふ心卵中の鶏胚の行なう酸 素消費や，与化後の七ナの体温にも日周期律動が観察 されている. 哺乳類ではラットなどの行動性, 体温, 酸素消費, 腸管に和ける糖の吸収, 肝臓のグリコーゲ ンあるいは燐脂質量または非蛋白性 SH, 副腎皮質木 ルモン，血中のコルチコステロイドおよび鉄などの濃 度, 好酸球, 淋巴球その他の白血球の数もこの種のリ ズムの下に消長して括り，下垂体の副腎皮質刺激ホル 